Comparison of the features of the relationship between children and parents according to the birth order in the family hierarchy

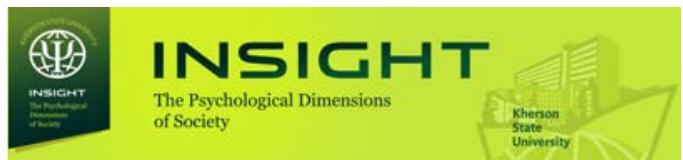

DOI: $10.32999 / 2663-970 X / 2020-3-7$

Link article (Style APA): Krupnyk, H. A. (2020). Comparison of the features of the relationship between children and parents according to the birth order in the family hierarchy. Insight: the psychological dimensions of society, 3, 97-108. DOI: 10.32999/2663-970X/2020-3-7

Link article (Style DSTU 8302: 2015): Krupnyk, H. A. Comparison of the features of the relationship between children and parents according to the birth order in the family hierarchy. Insight: the psychological dimensions of society, 2020, 3, 97-108. DOI: 10.32999/2663-970X/2020-3-7

UDC 159.9:316.362.1

\title{
Comparison of the features of the relationship between children and parents according to the birth order in the family hierarchy
}

\author{
Порівняння особливостей взаємин дітей з батьками \\ у підгрупах за порядком народження у сімейній ієрархії
}

Received: May 06, 2020 Accepted: June 08, 2020

\author{
Krupnyk Hanna Anatoliivna \\ Postgraduate student \\ Department of General and Social psychology \\ Kherson State University, Ukraine \\ kr.aa@i.ua, \\ ORCID 0000-0003-4277-1340
}

\author{
Крупник Ганна Анатоліївна \\ Аспірантка \\ кафедра загальної та соціальної психології \\ Херсонський державний університет, \\ Україна \\ kr.aa@i.ua, \\ ORCID 0000-0003-4277-1340
}

\begin{abstract}
The article reviews the results of the study of the state of the modern nuclear family. The author analyses scientific papers of the prominent domestic and foreign contemporary scientists in the area of the parent-child relations. It covers the features of the interrelation of parents with the firstand second-born children from the standpoint of the very respondents. The choice of methods for this group of respondents is substantiated. Purpose is to analyze the level of the development of parent-child relations and to compare the results of the groups according to the birth order of children in the family hierarchy. Methods: the questionnaire "Parents Child Interaction" (the author is I. Markovska), which contains 10 bipolar scales; statistical processing of empirical data and graphical presentation of results are carried out using the statistical program "MS Excel". Results: mother's behavior towards the second child is more demanding, with a higher level of responsibility and expectations, as well as a more balanced and controlling. It may be manifested in petty care, obtrusiveness, restraint, and general psychological infantilization of the younger child.
\end{abstract}

\section{Анотація}

У статті здійснено огляд результатів вивчення стану сучасної нуклеарної сім'ї. Проаналізовано наукові роботи провідних вітчизняних та закордонних новочасних науковців у руслі батьківсько-дитячих стосунків. Висвітлено особливості взаємодії батьків 3 першо- та другонародженими дітьми, з позиції самих опитуваних. Обгрунтовано вибір методики для цієї групи респондентів. Мета: дослідження рівня розвитку батьківсько-дитячих відносин та порівняння результатів у групах за порядком народження дітей у сімейній ієрархії. Методи: опитувальник “Взаємодія батьки - дитина” (Марковська, 1999), який містить 10 біполярних шкал; статистична обробка емпіричних даних і графічна презентація результатів здійснена за допомогою статистичної програми "MS Excel”. Результати: більш вимогливою, із більшим рівнем відповідальності та рівнем очікувань, а також більш виваженою контролюючою є поведінка матері стосовно своєї другої дитини. Це може виявлятися в дріб'язковій опіці, нав'язливості, обмежуванні та загалом психологічній інфантилізації молодшої дитини. Що ж до стосунків із батьком, то другі діти 
As for the relations with father, the second-born children in the nuclear family show their closeness to him and have a desire to share the most secret and important things with him. The author also finds out that the first-born child negatively describes his relations with father (disagreement, liberalism, excessive softness), and the frequency and degree of the agreement are traced regarding the second child in various life situations. The second child more positively comments his interrelation with father than the first-born. Conclusions: the relations of respondents with their parents are diametrically opposed when comparing the first child with the second. The principal provisions of research findings are the foundation for the development of specific recommendations which will be useful and assist the practical family psychologist consulting in such sub-systems as siblings, parentchild and marital relationships.

Key words: parent-child relationship, family group research, first and second child according to the birth order in family, educative competence of parents.

\section{Introduction}

Taking into account the transformational processes which the modern family experiences, it becomes relevant to extend the range of problems of psychological researches in the early XXI century, which is characterized by the increment of the marriage age, deferred paternity, growth of the number of childless or single-child families. The out of wedlock birth rate is growing, and the number of people who consciously choose singleness or unregistered marriages is increasing. New models of the partnership are emerging and spreading: extramarital partnerships and same-sex marriages. There is no doubt that under the current conditions, it is necessary to carry out comprehensive studies of the modern family and to search for the resources to overcome the abovementioned unfavorable phenomena.

The modern society is characterized by a high level of the advancement of various crisis manifestations that occur in the economic, social, cultural, political and many other spheres of human life, which directly affect the development of relations between family members - both adults and children.

Among the researchers of the modern family problems, the author marks the followings: $\mathrm{H}$. Karsten considered the behavioral aspects у нуклеарній сім'ї проявляють свою близькість саме до нього, мають бажання ділитися $з$ ним найпотаємнішим і важливим. Також нами виявлено, що первісток описує негативний характер взаємодії між ним та батьком (незгода, невимогливість, надмірна м'якість), а от частота і ступінь згоди простежується з другою дитиною в різноманітних життєвих ситуаціях. Друга дитина більш позитивно розцінює взаємодію з батьком, ніж перша за порядком народження у сім'ї. Висновки: стосунки, на які вказують опитувані щодо своїх батьків діаметрально протилежні при порівнянні першої дитини 3 другою. Основні положення за результатами нашого дослідження будуть покладені в основу розробки конкретних рекомендацій, які стануть корисними і допоможуть у подальшій роботі практичним психологам у сфері сімейного консультування у таких підсистемах, як сиблінгові, батьківсько-дитячі та подружні стосунки.

Ключові слова: дитячо-батьківські стосунки, дослідження родинної групи, перша та друга дитина за порядком народження у сім'ї, виховна компетентність батьків.

\section{Вступ}

Враховуючи трансформаційні процеси, які переживає сучасна родина, актуальними стають завдання розширення проблематики наукових досліджень у психології на початку XXI століття, яке характеризується збільшенням віку вступу у шлюб, відтермінуванням батьківства, збільшенням чисельності бездітних або однодітних сімей. Росте рівень народжуваності поза шлюбом, збільшується кількість людей, які свідомо обирають самотність або незареєстровані шлюбні стосунки. 3'являються та розповсюджуються нові моделі партнерства: позашлюбне партнерство та одностатеві шлюби. Безумовно, що при умовах, які склалися у наш час, необхідними являються вичерпні дослідження сучасної родини та пошук ресурсів для подолання вище зазначених неблагополучних явищ.

Сучасне суспільство характеризується високим рівнем розповсюдження різноманітних кризових подій, що появляються в економічній, соціальній, культурній, політичній та багатьох інших сферах життєдіяльності людини, які безпосередньо впливають на розвиток стосунків між членами родинної групи, як дорослими, так і дітьми. 
Comparison of the features of the relationship between children and parents according to the birth order in the family hierarchy

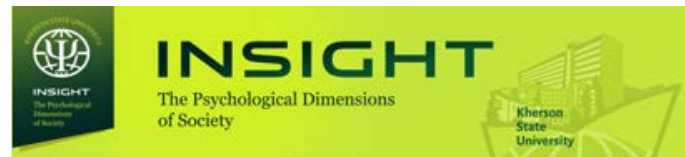

of the family relations (Karsten, 2018: 55), I. Krupnyk described the features of visions of the future family life of children from the migrant workers' families (Krupnyk, 2016: 146), T. Mostafa studied the influence of a complex structure of family on children welfare (Mostafa, 2017: 902), S. Tsiura analyzed outstanding characteristics of the pedagogical environment of siblings development (Tsiura, 2016: 149), D. Yucel observed the relations in the nuclear families (Yucel, 2018: 523).

The research activities of the prominent scientists focus on the importance to study family as an integral phenomenon taking into account the intercommunication inside the three sub-systems: marital, child-parents and sibling.

The leading scientists of the contemporary domestic and foreign psychology have made a substantial contribution to the study of the issue of personality development in the family and nature of parents-child interaction. The researchers focused on the study of such topical issues as the factors influencing the development of sibling interaction, relations between the elder and younger child within the family, as well as considered the requirements for the execution of the social roles by children and parental expectations (Krupnyk, 2019: 139).

Child-parent relations are bilateral where each party determines the genesis and development of the communication in cooperation of parents and a child; however, the roles of both parties are subjected to substantial changes at every age stage of their development.

The factors specifying the features of interpersonal relations inside the family are as follows: lifestyle and behavior within the family; the moral and cultural level of father and mother and their interrelations; the attitude of father and mother to their child; their realization and understanding of the purposes and tasks of the family education.

F. Spivakovska marks the breach of the system of family education, disharmony of family relations, which is a pathogen, can trigger the neurotic disorder of children (Spivakovska, 1986). The harmonious interpersonal relations of parents and children, which are based on humane attitude to a child and his acts, positively influence the formation of cognition interest of a child, the social and psychological adaptation of a personality.

It is worth noting that the growing personality is also affected by the relations with his sibling
Серед дослідників сучасної сімейної проблематики можна назвати таких авторів, як: Х.Карстен - розглядав аспекти поведінки у сімейних стосунках (Karsten, 2018: 55), I. Крупник - описував особливості уявлень про майбутнє сімейне життя дітей 3 родин трудових мігрантів (Крупник, 2016: 146), Т. Мостафа - вивчав вплив складної структури сім'ї на благополуччя дітей (Mostafa, 2017: 902), С. Цюра - досліджувала характерні особливості педагогічного середовища розвитку сиблінгів (Цюра, 2016: 149), Д. Юсель - простежувала взаємини у нуклеарних сім'яx (Yucel, 2018: 523).

у наукових розвідках провідних вчених наголошується на важливості вивчення сім'ї як цілісного феномена, із врахуванням взаємодії, що розгортається у трьох підсистемах: подружній, дитячо-батьківській та сиблінговій.

Вагомий внесок у дослідження проблеми розвитку особистості в сім'ї та характеру взаємовідносин між батьками та дітьми зроблено провідними науковцями сучасної вітчизняної та зарубіжної психології. Дослідники зосередилися на вивченні таких актуальних питань, як чинники, що впливають на розвиток сиблінгових взаємин, стосунки між старшою і молодшою дитиною у родині, а також розглядали вимоги до виконання соціальних ролей дітьми та батьківські очікування (Крупник, 2019: 139).

Дитячо-батьківські стосунки - двобічні, кожна сторона визначає генезу та розвиток спілкування у співпраці батьків та дитини, хоча, безумовно, ролі обох сторін зазнають значних змін на кожному з вікових етапів їх розвитку.

До факторів, що розкривають особливості міжособистісних взаємин у сім'ї, відносяться: спосіб життя й поведінка в сім'ї; моральний і культурний рівень батька й матері та їхні взаємини; відношення батька й матері до своєї дитини; усвідомлення й розуміння ними цілей, завдань сімейного виховання.

А. Співаковська зазначає, що до виникнення неврозів у дітей може призвести порушення системи сімейного виховання, дисгармонія сімейних взаємин, що являється патогенним чинником (Співаковська, 1986). Гармонійні міжособистісні взаємини батьків і дітей, в підгрунті яких полягає гуманне 
besides the level of development of parent-child relations and the style of parenting. A. Adler was one of the pioneers who carried out the most important studies of sibling relations. He stated that the birth order is a crucial factor of the personality development (Adler, 1998). In contrast, G. Craig stated that there are no such individual features which would exclusively depend on the birth order (Craig, 2000). E. Fromm paid attention to the maternal attitude towards children which affects the interrelations between siblings (Fromm, 1994). The psychologists Montgomery Scott, Bergh Cecilia, Ruzan mark that elder siblings may manifest adverse effects on the psychological development due to the possible high requirements for the family resources or cooperation between siblings (Montgomery, Bergh, Udumyan, 2018: 447).

Studying the state of the modern family group, one can demonstrate the fact that in Ukraine, there are mostly families with few children. Thus, when deciding on the birth of one more child, parents worry about such issues as the upbringing of happy and harmoniously developed personality and concern with the possible difficulties in the relationships between children and the personal pedagogic competence. To harmonize the relations between all family members, parents naturally make mistakes that can cause a psycho-traumatic effect on the development of a child's personality.

Hypothesis. The author suggests the upbringing style of mother and father differs towards children according to their birth order in the nuclear family.

The purpose of the research is to study the development level of parent-child relations and to compare the results in the groups according to the birth order of children in the family hierarchy.

\section{Methodology}

Following the purpose and subject of the research, the author gathers up methods which allows to identify the perception of children's relationships with their parents and lets respondents to assess their development.

I. Markovska, the author of the questionnaire "Parent-Child Interrelation", developed a mirror questionnaire, which has two forms - for parents and children. She stressed on the importance to get to know not only the assessment of one side - ставлення до дитини і її вчинків, позитивно впливають на формування пізнавального інтересу у дітей, соціально-психологічну адаптацію особистості.

Але зауважимо, що окрім рівня розвитку батьківсько-дитячих стосунків та стилю батьківського виховання, на зростаючу особистість впливають і стосунки з ії сиблінгом. Найбільш вагомі дослідження сиблінгових стосунків здійснив одним із перших А. Адлер. Він доводив, що порядок народження - це важливий фактор розвитку особистості (Адлер, 1998). На противагу ж йому, Г. Крайг зазначав, що фактично не існує таких індивідуальних особливостей, які залежали б тільки від порядку народження (Крайг, 2000). Е. Фром звертав увагу на материнське ставлення до дітей, яке впливає на взаємовідносини між сиблінгами (Фром, 1994). Психологи Montgomery Scott, Bergh Cecilia, Ruzan зазначають, що у старших сиблінгів можуть виявлятися більш несприятливі наслідки для психологічного розвитку, пов'язуючи це з можливою причиною, що відбувається через більш високі вимоги до сімейних ресурсів або взаємодії між братами і сестрами (Montgomery, Bergh, Udumyan, 2018: 447).

Вивчаючи стан сучасної родинної групи, можна констатувати той факт, що в Україні здебільшого малодітні сім'ї. Отож, вирішуючи питання з народженням ще однієї дитини, батьків хвилюють такі значущі питання, як бажання виховати щасливу та гармонійно розвинену особистість, турбують можливі труднощі у взаєминах між дітьми та власна педагогічна компетентність. Намагаючись гармонізувати стосунки між усіма членами сім'ї, батьки, певна річ, припускаються і помилок, що можуть наносити психотравмуючий вплив на розвиток особистості дитини.

Гіпотеза. Автор припускає, що стиль виховання матері та батька відрізняється по відношенню до дітей за їхнім порядком народження у нуклеарній сім'ї.

Метою статті $€$ дослідження рівня розвитку батьківсько-дитячих відносин та порівняння результатів у групах за порядком народження дітей у сімейній ієрархії.

\section{Методологія}

Згідно мети і предмету дослідження нами було підібрано методику, що дозволяє виявити 
parents, but also the vision of this interaction on the part of children (I. Markovska, 1999: 94).

The psychological sources most often mark the following parameters of interaction of parents with a child: autonomy-control, rejection-acceptance, and exactingness, a degree of emotional closeness and attachment, strictness, inconsistency-consistency. I. Markovska used these parameters for the scales of the questionnaire of the interaction of parents with children. The questionnaire also includes the scales "cooperation" and "agreement" as the essential elements of interaction. Moreover, according to the author of the method one of the most important indicators is the degree of parental satisfaction with the process of interaction with children. Consequently, the scale "satisfaction" was included in both adult and children's versions of the questionnaire.

The article's author uses the adolescent version to clarify the perception of such interaction by children towards parents through assessing the education influence of their parents.

The questionnaire includes 60 questions and has 10 bipolar scales, as well as proposes respondents to appraise the competence of father and mother separately.

\section{Participants}

The students of Kherson College of Culture of Kherson Regional State Administration and Kherson State University participated in the research. The sample group of 64 respondents was unified into two subgroups according to the birth order of children in the nuclear family. Among them, there are the firstborns - 29 people, and the children who are the second in the family hierarchy -35 .

The sub-group of the first-borns consists of $17.24 \%$ of boys and $82.76 \%$ of girls. The average age is 17.79 years, and an average age of their younger siblings is 10.76 and 8.33 years, respectively. Nuclear families of this sample have two children $-72.41 \%$, three children $-27.59 \%$. Parents mainly have higher educational attainment, and the financial position is average. $48.28 \%$ of the respondents live in the city and $51.72 \%$ - in the village.

The sub-group of the second-born children consists of $14.29 \%$ of boys and $85.71 \%$ of girls. The average age -17.89 and the age range of their older siblings is 26.46 years and younger sib- сприймання стосунків дітей зі своїми батьками та надати можливість респондентам оцінити їх розвиток.

Автор опитувальника "Взаємодія батьки дитина” I. Марковська розробила дзеркальний опитувальник, який має дві форми - для батьків і для дітей. Вона наголошувала, що важливо знати не тільки оцінку однієї сторони - батьків, але і бачення цієї взаємодії з боку дітей (Марковська, 1999: 94).

У психологічній літературі найчастіше виділяються такі параметри взаємодії батьків з дитиною, як автономія-контроль, відкидання-прийняття, вимогливість, ступінь емоційної близькості, прихильності, строгість, непослідовність-послідовність. Ці параметри були взяті I. Марковською як підстави для шкал опитувальника взаємодії батьків з дітьми. До опитувальника увійшли також шкали "співпраця” і “згода” як важливі параметри взаємодії. Окрім того, на думку автора методики, одним 3 найважливіших показників $є$ ступінь задоволеності батьків процесом взаємодії з дітьми. Відповідно, шкала “задоволеність" увійшла і в дорослий, і у дитячий варіанти опитувальника.

У нашому дослідженні ми використали підлітковий варіант з метою виявлення сприймання цієї взаємодії з боку дітей до батьків, маючи можливість оцінити виховний вплив своїх батьків.

Опитувальник включає в себе 60 запитань, що містить у собі 10 біполярних шкал та пропонує респондентам окремо атестувати компетентність батька та матері.

\section{Учасники}

У дослідженні взяли участь студенти Комунального вищого навчального закладу "Херсонське училище культури" Херсонської обласної ради та Херсонського державного університету. Вибірку з 64 респондентів було об'єднано у дві підгрупи за порядком народження дітей у нуклеарній сім'ї. Із них первістки - 29 осіб, а дітей, що являються другими у сімейній ієрархії - 35.

Підгрупа первістків складається з 17,24\% хлопців та 82,76\% дівчат. Середній вік 17,79 років, аїх молодші сиблінги маютьсередній вік 10,76 і 8,33 роки відповідно. Нуклеарні сім'ї даної вибірки складаються із двох дітей 
lings - 14.78 and 8.5 years, respectively. The nuclear families of this group consist of two children $-68.57 \%$, three children $-25.71 \%$, and four children $-5.54 \%$. Mothers mainly have vocational education and fathers - higher educational attainment, and the financial position is the same as in the first sub-group - average. 54.29\% live in the city and $45.71 \%$ - in the village.

\section{Procedure and tools}

When completing the questionnaire "Parent-Child Interaction", the respondents were asked to indicate the level of agreement with each statement on a five-point scale.The total number of points on each scale is calculated, taking into account whether the statements are direct or inverse.

The questionnaire includes the 10 following scales and describes their interpretation in details:

1) Liberalism - exactingness of parents.

2) Softness - strictness of parents.

3) Autonomy - control over a child.

4) Emotional distance - the emotional closeness of a child to his parents.

5) Rejection -acceptance of a child by parents.

6) Lack of cooperation - cooperation.

7) Disagreement - agreement between a child and parents.

8) Inconsistency - consistencyof parents.

9) Authority of parents.

10) Satisfaction with relationship with parents.

\section{Statistical analysis}

The statistical processing of the empirical data and graphic presentation of the findings are realized through the statistical program "MS Excel".

\section{Results}

According to the I. Markovskaya method of "Child-Parent Interaction", the following average test results were obtained.

Consequently, one may state that mother is more demanding, strict and controlling in relation to the second child; she requires strict compliance with her rules of conduct and expects a high level of personal responsibility. And father, on the contrary, is undemanding, soft and provides more autonomy to the first-born, gives more freedom of will, which sometimes verges on a total absence of authority. The before mentioned may indicate у кількості 72,41\%, із трьох дітей - 27,59\%. Освіта у батьків переважно вища, матеріальний стан - середній. Проживають у місті $48,28 \%$ респондентів, а у селі - 51,72\%.

Підгрупа другонароджених дітей складається із 14,29\% хлопців та 85,71\% дівчат. Середній вік - 17,89, віковий діапазон їх старших сиблінгів становить 26,46 років, а молодших 14,78 та 8,5 років відповідно. Нуклеарні сім'ї цієї підгрупи складаються із двох дітей у кількості $68,57 \%$, трьох дітей - $25,71 \%$, а чотирьох дітей - 5,54\%. Освіта у матерів переважно професійно-технічна, а у батьків переважно вища, матеріальний стан, як і у представників першої підгрупи - середній. Проживають у місті $54,29 \%$ респондентів, а у селі $-45,71 \%$.

\section{Процедура та інструменти}

При заповненні опитувальника "Взаємодія батьки - дитина" респондентам пропонується оцінити ступінь згоди з кожним твердженням за п’ятибальною системою. Підраховується загальна кількість балів по кожній шкалі, при цьому враховується, прямі це твердження або зворотні.

В опитувальнику представлені 10 наступних шкал та детально описана їх інтерпретація:

1) Невимогливість - вимогливість батьків.

2) М'якість - строгість батьків.

3) Автономність - контроль по відношенню до дитини.

4) Емоційна дистанція - емоційна близькість дитини до батьків.

5) Відкидання - прийняття дитини батьками.

6) Відсутність співпраці - співробітництво.

7) Незгода - згода між дитиною і батьками.

8) Непослідовність - послідовність батьків.

9) Авторитетність батьків.

10) Задоволеність стосунками дитини з батьками.

\section{Статистичне аналізування}

Статистичну обробку емпіричних даних і графічну презентацію результатів здійснено за допомогою статистичної програми "MS Excel".

\section{Результати}

За методикою "Взаємодія батьки - дитина" I. Марковської були отримані такі середні значення у цілому за тестом (див. табл. 1) 


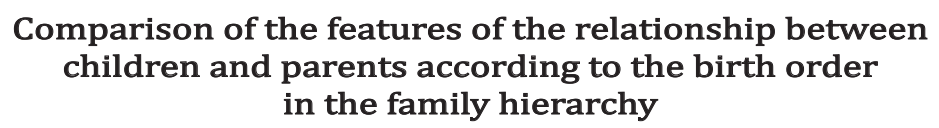

Table 1. The average results of the first- and second-born children with mother and father according to the questionnaire "Child-Parent Interaction"

Таблиця 1. Середні значення результатів за опитувальником “Взаємодія батьки - дитина” ерших та других дітей за порядком народження з матір’ю та батьком

\begin{tabular}{|c|c|c|c|c|}
\hline \multirow[b]{2}{*}{$\begin{array}{l}\text { Scales } \\
\text { Шкали }\end{array}$} & \multicolumn{2}{|c|}{$\begin{array}{l}\text { Relationship with mother } \\
\text { Взаємини з матір'ю }\end{array}$} & \multicolumn{2}{|c|}{$\begin{array}{l}\text { Relationship with father } \\
\text { Взаємини з батьком }\end{array}$} \\
\hline & $\begin{array}{l}\text { The first-born } \\
\text { child in the family } \\
\text { (n=29) } \\
\text { Перша дитина y } \\
\text { сім'ї (n=29) }\end{array}$ & $\begin{array}{l}\text { The second-born } \\
\text { child in the } \\
\text { family }(n=35) \\
\text { Друга дитина y } \\
\text { сім'ї }(n=35)\end{array}$ & $\begin{array}{l}\text { The first-born } \\
\text { child in the family } \\
\text { (n=29) } \\
\text { Перша дитина y } \\
\text { сім'ї }(n=29)\end{array}$ & $\begin{array}{l}\text { The second-born } \\
\text { child in the } \\
\text { family(n=35) } \\
\text { Друга дитина y } \\
\text { сім'ї }(n=35) \\
\end{array}$ \\
\hline $\begin{array}{l}\text { Liberalism } \\
\text { - exactingness } \\
\text { Невимогливість } \\
\text { - вимогливість } \\
\end{array}$ & 13,41 & 14,77 & 12,03 & 12,66 \\
\hline $\begin{array}{l}\text { Softness - strictness } \\
\text { М'якість - строгість }\end{array}$ & 12,00 & 12,91 & 10,66 & 11,51 \\
\hline $\begin{array}{l}\text { Autonomy - control } \\
\text { Автономність } \\
\text { - контроль } \\
\end{array}$ & 14,59 & 15,77 & 12,41 & 13,21 \\
\hline $\begin{array}{l}\text { Emotional distance } \\
\text { - closeness } \\
\text { Емоційна дистанція } \\
\text { - близькість } \\
\end{array}$ & 18,59 & 18,77 & 13,00 & 15,40 \\
\hline $\begin{array}{l}\text { Rejection } \\
\text { - ассерtance } \\
\text { Відкидання } \\
\text { - прийняття } \\
\end{array}$ & 19,62 & 18,86 & 16,12 & 18,10 \\
\hline $\begin{array}{l}\text { Lack of cooperation } \\
\text { - cooperation } \\
\text { Відсутність } \\
\text { співпраці } \\
\text { - співробітництво }\end{array}$ & 17,76 & 17,37 & 12,69 & 14,60 \\
\hline $\begin{array}{l}\text { Disagreement } \\
\text { - agreement } \\
\text { Незгода - згода }\end{array}$ & 14,76 & 15,26 & 12,10 & 14,34 \\
\hline $\begin{array}{l}\text { Inconsistency } \\
\text {-consistency } \\
\text { Непослідовність } \\
\text { - послідовність }\end{array}$ & 17,00 & 16,49 & 15,28 & 16,57 \\
\hline $\begin{array}{l}\text { Authority of parents } \\
\text { Авторитетність } \\
\text { батьків }\end{array}$ & 18,90 & 18,17 & 14,34 & 15,91 \\
\hline $\begin{array}{l}\text { Satisfaction with } \\
\text { relationship with } \\
\text { parents } \\
\text { Задоволеність сто- } \\
\text { сунками з батьками }\end{array}$ & 19,45 & 19,74 & 14,90 & 17,86 \\
\hline
\end{tabular}

a weak educational influence and be the result of indifference to his descendant.

The parents have close emotional ties with the second child - this is manifested in the desire of younger children to share their important life events both with mother and father.
Отже, можна засвідчити, що мати більш вимоглива, строга та контролююча по відношенню до другої дитини, вимагає суворого виконання окреслених нею правил поведінки та очікує великого рівня особистісної відповідальності, а батько, навпаки, невимогливий, 
Mother demonstrates the acceptance of a child and cooperation towards the elder child, i.e. she is fully satisfied with the personal traits and behavior of the first-born while father tends to the second child that influences the favorable psychological development and positive self-esteem of the younger child.

The agreement in the relationship is observed between the mother and the younger child that indicates the harmony between them and a positive relationship, and disagreement - between the father and the first-born, that is, children note the difference between them in views on different life situations.

The consistency in the education and the authority are peculiar to the mother and the first child, м'який та надає більше автономності первісткові, дає більшої свободи волі, яка іноді межує із вседозволеністю. Це може вказувати на слабкий виховний вплив, бути наслідком байдужого ставлення до свого нащадка.

Емоційно близькими дорослі виявляються до другої дитини - це проявляється у бажанні молодших дітей ділитися важливими подіями зі свого життя як з мамою, так і з татом одночасно.

Прийняття дитини та співробітництво проявляється у матері до старшої дитини, тобто iï цілком задовольняють особистісні якості та поведінкові прояви первістка, а у батька до другої, що впливає на сприятливий психологічний розвиток та позитивну самооцінку молодшої дитини.

Table 2. The differences in the test scores of the first- and second-born children on the interaction with the mother according to the questionnaire "Parent-Child Interaction" (Student's t-test)

Таблиця 2. Відмінності тестових оцінок за опитувальником “Взаємодія батьки - дитина” перших та других дітей за порядком народження із матір’ю (t-критерій Стьюдента)

\begin{tabular}{|c|c|c|c|c|}
\hline $\begin{array}{c}\text { Interaction } \\
\text { with the mother } \\
\text { Взаємодія } 3\end{array}$ & $\begin{array}{c}\text { The first-born child } \\
\text { in the family }(n=29) \\
\text { Перша дитина y } \\
\text { сім'ї }(n=29)\end{array}$ & $\begin{array}{l}\text { The second-born child } \\
\text { in the family }(n=35) \\
\text { Друга дитина у сім'ï } \\
(n=35)\end{array}$ & \multirow[t]{2}{*}{$\begin{array}{l}\text { Student's t-test } \\
\text { t-критерій } \\
\text { Стьюдента }\end{array}$} & \multirow[t]{2}{*}{$\begin{array}{c}\text { Significance level } \\
\text { Рівень } \\
\text { значущості }\end{array}$} \\
\hline матір'ю & \multicolumn{2}{|c|}{$\begin{array}{c}\text { Average score } \\
\text { Середній бал }\end{array}$} & & \\
\hline $\begin{array}{c}\text { Exactingness } \\
\text { Вимогливість }\end{array}$ & 13,41 & 14,77 & 1,82 & $\mathrm{p} \leq 0,1$ \\
\hline $\begin{array}{c}\text { Control } \\
\text { Контроль }\end{array}$ & 14,59 & 15,77 & 1,66 & $\mathrm{p} \leq 0,1$ \\
\hline
\end{tabular}

Table 3. The differences in the test scores of the first- and second-born children on the interaction with the father according to the questionnaire "Parent-Child Interaction" (Student's t-test) Таблиця 3. Значущі відмінності тестових оцінок за опитувальником «Взаємодія батьки - дитина» перших та других дітей за порядком народження із батьком (t-критерій Стьюдента)

\begin{tabular}{|c|c|c|c|c|}
\hline $\begin{array}{c}\text { Interaction } \\
\text { with the father } \\
\text { Взаємодія } 3\end{array}$ & $\begin{array}{l}\text { The first-born } \\
\text { child in the family } \\
\text { (n=29) } \\
\text { Перша дитина y } \\
\text { сім'ї }(n=29)\end{array}$ & $\begin{array}{c}\text { The second-born child } \\
\text { in the family }(\mathrm{n}=35) \\
\text { Друга дитина у сім'ï } \\
(\mathrm{n}=35)\end{array}$ & \multirow[t]{2}{*}{$\begin{array}{c}\text { Student's t-test } \\
\text { t-критерій } \\
\text { Стьюдента }\end{array}$} & \multirow[t]{2}{*}{$\begin{array}{l}\text { Significance level } \\
\text { Рівень значущості }\end{array}$} \\
\hline & \multicolumn{2}{|c|}{$\begin{array}{l}\text { Average score } \\
\text { Середній бал }\end{array}$} & & \\
\hline $\begin{array}{c}\text { Emotional closeness } \\
\text { Емоційна } \\
\text { близькість } \\
\end{array}$ & 13,00 & 15,40 & 1,88 & $\mathrm{p} \leq 0,1$ \\
\hline $\begin{array}{c}\text { Disagreement } \\
\text { - agreement } \\
\text { Незгода - згода }\end{array}$ & 12,10 & 14,34 & 2,27 & $\mathrm{p} \leq 0,05$ \\
\hline $\begin{array}{c}\text { Satisfaction with } \\
\text { relationship with } \\
\text { parents } \\
\text { Задоволеність сто- } \\
\text { сунками з батьками }\end{array}$ & 14,90 & 17,86 & 1,90 & $\mathrm{p} \leq 0,1$ \\
\hline
\end{tabular}


Comparison of the features of the relationship between children and parents according to the birth order in the family hierarchy

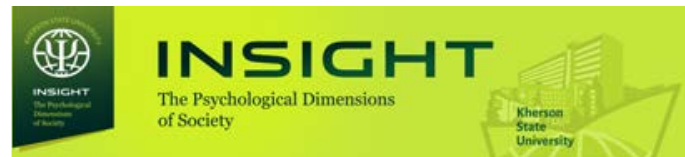

and father shows these characteristics towards the second child.

The second-born children in the family hierarchy point at the satisfaction with the relationship with both parents that confirms the lack of disorders in the interrelations or conflicts in the child-parent subsystem of family relations. Thus, the author can prove the theory of A. C. Jensen та S. M. McHale, who once drew attention to the issues of the first- and the second-born children. They marked that it is observed less conflict and more warmth on the part of both mothers and fathers primarily to the second-born adolescents (Jensen, McHale, 2017: 119).

It is necessary to consider those statements where the difference in results is confirmed in more details (or the tendency is observed) using Student's t-test (see tables 2, 3).

The author traces the differences in the relationship with the mother between the first and second children according to the birth order in the family hierarchy. The scale "Liberalism - exactingness" shows a tendency that the mother is more demanding and has a higher degree of responsibility and the level of expectations towards her second child $(t=1,82 ; p \leq 0,1)$.

Under the scale "Autonomy - control", there is a tendency of more apparent controlling behavior of mother in relation to the second child $(t=1,66$; $\mathrm{p} \leq 0,1)$. This can be manifested in petty care, obtrusiveness, restraint, and general psychological infantilization of the younger child.

Table 3 shows the level of development of relationships between father and children that permits monitoring the differences in their interaction.

The scale "Emotional distance - closeness" confirms a tendency that the second children in the nuclear family express their closeness to the father and have a desire to share the most secret and important things with him $(\mathrm{t}=1.88 ; \mathrm{p} \leq 0.1)$.

The scale "Agreement - disagreement" demonstrates statistically substantive differences $(t=2.27 ; \mathrm{p} \leq 0.05)$, i. e. it describes the negative nature of the interaction of the first child with father simultaneously reflecting the frequency and degree of father's agreement with the second child on different life situations.

The author finds the tendency under the scale "Satisfaction with the relations with parents" $(t=1.90 ; p \leq 0.1)$, i.e. the second child more posi-
Згода у взаєминах проявляється між матір'ю та молодшою дитиною, що свідчить про узгодженість між ними та позитивні стосунки, а незгода - між батьком та первістком, тобто діти відмічають розбіжність між ними в поглядах на різні життєві ситуації.

Послідовність у вихованні та авторитетність виокремлено між матір'ю та першою дитиною, а у батька ці показники проявляються по відношенню до другої дитини.

На задоволеність стосунками з обома батьками вказують другі діти за порядком народження у сімейній ієрархії, що свідчить про відсутність порушень у взаєминах чи конфліктів у дитячо-батьківській підсистемі родинних стосунків. Тому, можемо підтвердити теорію A. C. Jensen та S. M. McHale, які свого часу звернули увагу на першо- та другонароджених дітей і вказали, що спостерігають менший конфлікт і велику теплоту з боку як матерів, так і батьків, у першу чергу стосовно другонароджених дітей підліткового віку (Jensen, McHale, 2017: 119).

Слід більш детально розглянути ті твердження, де різниця в результатах підтверджена (або спостерігається тенденція) за допомогою t-критерію Стьюдента (див. табл. 2; 3).

Простежимо відмінності у стосунках з матір'ю між першими та другими дітьми за порядком народження у сімейній ієрархіі. У шкалі "Вимогливість - невимогливість” виявляється тенденція, що більш вимогливою, із більшим рівнем відповідальності та рівнем очікувань мати відноситься до своєї другої дитини $(\mathrm{t}=1,82 ; \mathrm{p} \leq 0,1)$.

За шкалою "Автономність - контроль" також простежується тенденція, що більш вираженою $\epsilon$ контролююча поведінка матері і проявляється по відношенню до другої дитини $(\mathrm{t}=1,66$; $\mathrm{p} \leq 0,1)$. Це може виявлятися в дріб'язковій опіці, нав'язливості, обмежуванні та загалом психологічній інфантилізації молодшої дитини.

У таблиці 3 ми маємо змогу розглянути рівень розвитку стосунків між батьком та дітьми, що дає можливість відстежити розрізнення у їх взаємодії.

Шкала "Емоційна дистанція - близькість" свідчить про тенденцію, що другі діти у нуклеарній сім'ї проявляють свою близькість саме до батька, мають бажання ділитися з ним найпотаємнішим і важливим $(\mathrm{t}=1,88 ; \mathrm{p} \leq 0,1)$.

Шкала "Незгода - згода" має статистично значущі відмінності ( $\mathrm{t}=2,27 ; \mathrm{p} \leq 0,05)$, а саме описує негативний характер взаємодії між першою дитиною з батьком, водночас відображаючи 
tively evaluates the interaction with father than the first-born.

\section{Discussion}

The author has reason to argue the obtained research findings verify the hypothesis, namely: parents treat their children differently without realizing it. Consequently, this fact justifies that conflicts between siblings are caused by jealousy to parents.

To clarify the situation, figures 1,2 demonstrate the diagrams confirming the opposed influence of parents on their children based on the research findings.

Interaction of the mother with the second child Взаємодія матері з другою дитиною

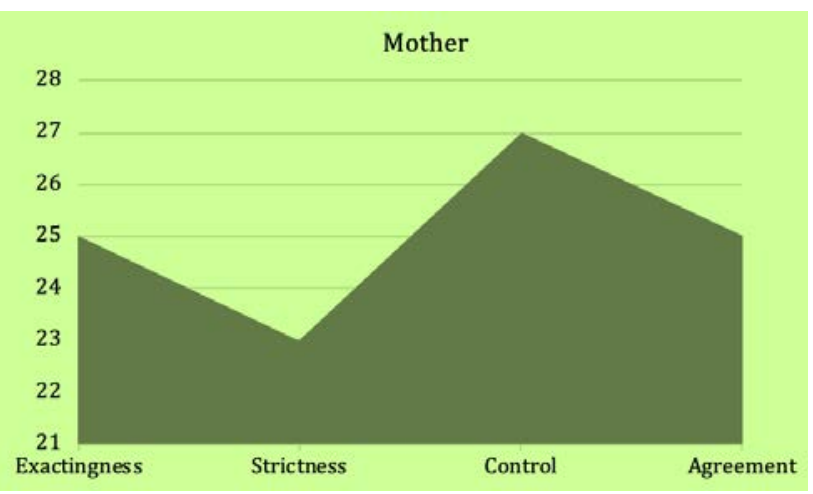

Fig. 1. Features of the relationships between mother and the second-born child

Рис. 1. Особливості стосунків між матір'ю та другонародженою дитиною

Interaction of father with the first-born

Взаємодія батька з першою дитиною

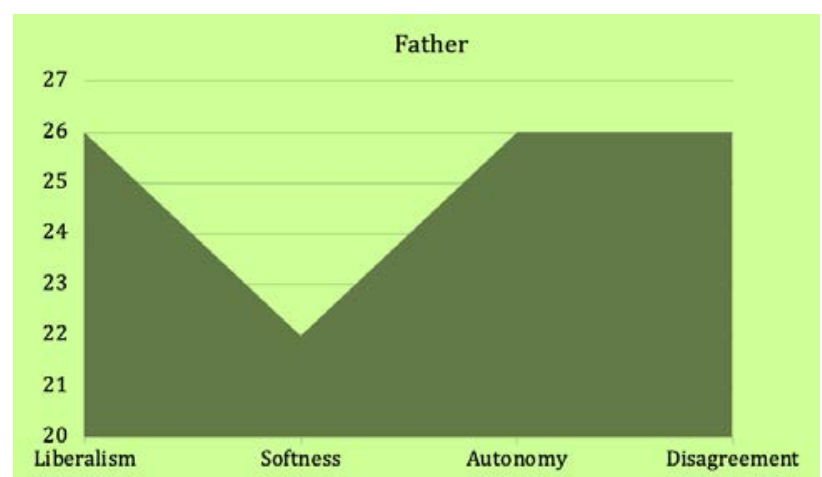

Fig. 2. Features of the relationships between father and the first-born

Рис. 2. Особливості стосунків між батьком та першонародженою дитиною частоту i міру згоди батька зі своєю другою дитиною в різних життєвих ситуаціях.

Також тенденція простежується і за шкалою “Задоволеність стосунками з батьками” ( $\mathrm{t}=1,90$; $\mathrm{p} \leq 0,1)$, тобто друга дитина більш позитивно розцінює взаємодію з батьком, ніж первісток.

\section{Дискусія}

Маємо підстави стверджувати, що отримані результати дослідження підтвердили нашу гіпотезу, а саме - батьки та матері по-різному ставляться до своїх дітей, іноді навіть не усвідомлюючи цього. Даний факт, у свою чергу, підтверджує те, що часто конфлікти між сиблінгами бувають через ревнощі до батьків.

Для більшої виразності на рис. 1, 2 продемонстровано діаграми, що засвідчують діаметрально протилежний вплив батьків на їх дітей за результатами нашого дослідження.

Тобто наші респонденти, що являються другими дітьми за порядком народження, відчувають на собі гіперопіку матері, яка у свою чергу розцінюється нею як турбота і бажання дати дитині усе найкраще.

Батьківський вплив продемонстровано на наступному графічному зображенні і вказує на вседозволеність, поблажливість, слабкий виховний вплив, що може бути наслідком байдужого ставлення або, навпаки, прискіпливого ставлення до вчинків первістка.

Як бачимо з проілюстрованого матеріалу стосунки, на які вказують опитувані щодо своїх батьків, відрізняються при порівнянні першої дитини з другою. Тобто мати по відношенню до молодшої дитини використовує авторитарний стиль виховання. Батько ж, навпаки, у вихованні першої дитини дотримується ліберального стилю виховання.

\section{Висновки}

Для більш повної картини вважаємо за необхідне вивчити батьківське ставлення до своїх дітей та порівняти результати 3 даним опитуванням. Адже не тільки батьки, а й самі діти ставляться один до одного по-різному, використовуючи методи пристосування чи маніпулювання. Адже не буває однакової реакції на одну й ту ж подію у кожного із членів родинної групи. На стиль спілкування впливає також і життєвий сценарій різних поколінь у даній 
In other words, our respondents, who are the second-born children, feel the hyperprotection of mother which she considers as care and striving to give the child all the best.

Father's influence is demonstrated at the following graphic, which indicates a total absence of authority, liberalism, weak educational influence, which may be the result of indifference or, conversely, meticulous attitude to the actions of the first-born.

As the illustrated material shows, the relations described by the respondents regarding their parents differ when comparing the first child with the second. Thus, the mother applies the authoritarian education style to the younger child. And father, contrarily, follows liberal education style towards the first-born.

\section{Conclusions}

For the sake of clarity, the author considers it necessary to study the parental attitude towards their children and to compare the results with this survey. Moreover, not only parents but also the very children treat each other differently by using the methods of adaptation or manipulation. There's no such thing as the identical reaction to the same event of each family member. Communication style is also influenced by the life scenario of different generations in the family, as well as dependence on the society where the individual lives.

Various factors affect the interrelations: general worldview and family traditions, patience, trust, ability to forgive, desire to agree to concessions, love, mutual understanding, features of individual development, level of development of cognitive processes and intelligence, special aspects of internal mental structure.

Thus, having regard to the above, one can emphasize that the fundamental provisions of the research findings can be a basis for the development of specific recommendations which would be useful and help in the further activities of practical psychologists in the area of family consulting of such sub-systems as sibling, parent-child and marital relations. Moreover, the family atmosphere created by parents is a more important factor for child development than the birth order itself. Consequently, the author is going to study the impact of parenting on the development of interaction between siblings in the nuclear family in further research. сім'ї, а також залежність від соціуму, у якому проживає особистість.

На взаємини впливають різноманітні чинники: загальний світогляд та родинні традиції, терпіння, довіра, уміння пробачати, бажання рухатись на зустріч, любов, взаєморозуміння, особливості індивідуального розвитку особи, рівень розвитку пізнавальних процесів та інтелекту, особливості внутрішньо-психічної структури.

Отже, виходячи з вище сказаного, можна наголосити на тому, що основні положення за результатами нашого дослідження можуть бути покладені в основу розробки конкретних рекомендацій, які будуть корисними і допоможуть у подальшій роботі практичним психологам у сфері сімейного консультування у таких підсистемах, як сиблінгові, батьківсько-дитячі та подружні стосунки. Адже сімейна атмосфера, створена батьками, $є$ більш важливим фактором розвитку дітей, ніж порядок народження сам по собі. Отже, нами заплановано у подальших дослідженнях вивчити вплив батьківського виховання на розвиток взаємин між сиблінгами у нуклеарній сім'ї.

\section{Список використаних джерел}

Адлер А. Воспитание детей: Взаимодействие полов. Пер. с англ. А.А. Валеев, Р.А. Валеева. Ростов н / Д: Феникс, 1998. 448 с.

Alexander C. Jensen, Susan M. McHale. Mothers', fathers', and siblings' perceptions of parents' differential treatment of siblings. Links with family relationship qualities Journal of Adolescence. Vol. 60, pp. 119-129 (date of publication: October 2017). DOI: $10.1016 /$ j.adolescence.2017.08.002

Крайг, Г. Психология развития. СПб., 2000. 992 с.

Фром Е. Азбука для батьків. Москва, 1994. 288 с.

Hank Karsten, Steinbach Anja. Intergenerational solidarity and intragenerational relations between adult siblings. Social science research. Vol. 76, pp. 55-64, (date of publication: NOV 2018). DOI: 10.1016/j.ssresearch.2018.08.003

Крупник Г. А. Огляд сучасних закордонних досліджень у сімейній сиблінговій підсистемі. Соціокультурні та психологічні виміри становлення особистості. Зб.наук.праць за матеріалами II Міжнародної науковопрактичної конференції / ред.колегія: О.Є. Блинова, Н. І. Тавровецька. Херсон, 2019. C. 139-142.

Крупник I. P. Проблеми дослідження особливостей уявлень про майбутнє сімейне життя дітей 3 родин трудових мігрантів. Науковий вісник Херсонського державного університету. Серія: 


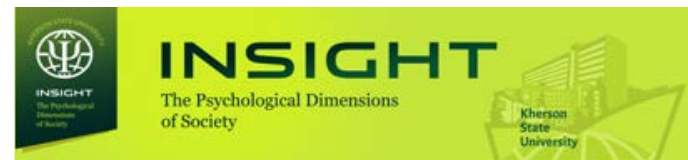

\section{References}

Adler, A. (1998). Parenting: the interaction of the sexes. Rostov-on-don: Feniks.

Alexander, C. Jensen, S. \& McHale, M. (2017). Mothers', fathers', and siblings' perceptions of parents' differential treatment of siblings: Links with family relationship qualities. Journal of Adolescence, 60, 119-129. DOI: 10.1016/j.adolescence.2017.08.002

Craig, G. (2000). Developmental psychology. Saint Petersburg.

From, E. (1994). ABC for parents. Moscow.

Hank, K. \& Steinbach, Anja. (2018). Intergenerational solidarity and intragenerational relations between adult siblings. Social science research. Vol. 76. 55-64. DOI: 10.1016/j.

Krupnyk, H. (2019). Review of current foreign research in the family sibling sub-system. Socio-cultural and psychological dimensions of personality formation. Collection of scientific papers on the materials of the II International scientific and practical conference. Kherson, 139-142.

Krupnyk, I. (2016). Problems of research of features of representations about future family life of children from families of labor migrants. Scientific Bulletin of Kherson State University. Series "Psychological Sciences", 1(1). 146-150.

Markovskaya, I. (1999). A questionnaire for studying the interaction of parents with children. Family psychology and family therapy, 2. 94-108.

Montgomery, S., Bergh, Cecilia \& Udumyan, R. (2018). Sex of older siblings and stress resilience. Longitudinal and life course studies, 9(4), 447-455.

Mostafa, T., Gambaro, L. \& Joshi, H. (2018). The Impact of Complex Family Structure on Child Well-being: Evidence From Siblings. Journal of marriage and family, 80(4), 902-918. DOI: 10.1016/j.

Spivakovskaja, A. (1986). How to be parents (About the psychology of parental love). Moscow.

Tsiura, S. (2016). Characteristic features of the pedagogical environment of sibling development. Bulletin of the Lviv University. Series: pedagogical: Collection of scientific works, 30, 149-151.

Yucel, D., Bobbitt-Zeher, D. \& Downey, D. (2018). Quality Matters: Sibling Relationships and Friendship Nominations among Adolescents. Child indicators research, 11, 523-539.

\section{Krupnyk Hanna}

Психол. науки: зб. наук. праць. Херсон, 2016. Вип. 1. Том 1. С. 146-150.

Марковская И.М. Опросник для изучения взаимодействия родителей с детьми. Семейная психология и семейная терапия. 1999. № 2. C. 94-108.

Montgomery Scott, Bergh Cecilia, Udumyan Ruzan. Sex of older siblings and stress resilience. Longitudinal and life course studies. Vol. 9, No4, P.447-455 (date of publication: OCT 2018) DOI: 10.14301/llcs. v9i4.486

Mostafa Tarek, Gambaro Ludovica, Joshi Heather. The Impact of Complex Family Structure on Child Well-being: Evidence From Siblings. Journal of marriage and family. Vol. 80, No4, P. 902- 918 (date of publication: AUG 2018). DOI: 10.1016/j.ssresearch.2017.12.007

Спиваковская А.С. Как быть родителями (0 психологии родительской любви). Москва, 1986. 160 c.

Цюра С.Б. Характерні особливості педагогічного середовища розвитку сиблінгів. Вісник Львівськогоуніверситету. Серія: педагогічна: Зб. наук. праць. Вип. 30. Львівський національний університет імені Івана Франка. Львів: Вид-во Львів. нац. ун-т, 2016. С. 149-151.

Yucel Deniz, Bobbitt-Zeher Donna, Downey Douglas B. Quality Matters: Sibling Relationships and Friendship Nominations among Adolescents. Child indicators research. Vol. 11, P. 523- 539 (date of publication: APR 2018). DOI: $10.1007 / \mathrm{s} 12187-$ 017-9448-9 